\title{
Życie i działalność cerkiewna metropolity Siergieja (Stragorodzkiego) do publikacji Deklaracji (1927)
}

\author{
Kamila Pawełczyk-Dura \\ Archiwum Państwowe w Łodzi \\ Polska \\ pawelczyk.kamila@wp.pl
}

\begin{abstract}
Kamila Pawełczyk-Dura, The Life and Church Activity of Metropolitan Sergius (Stragorodsky) Until the Publication of the Declaration (1927), Elpis, 18 2016: 157-163.

Abstract: The most important questions facing Russian Orthodox Church in the 20th century were undoubtedly the relations between the Church and communist state. One of the projects of legalization of the Church in the Soviet Union was created by Metropolitan Sergius (Stragorodsky) of Nizhny Novgorod, the deputy Patriarchal locum tenens (1925-1937) subsequently Patriarchal locum tenens (1937-1943) and Patriarch of Moscow (1943-1944). His famous Declaration of Loyalty, dated 1927 July 16/29, originated in the views of patriarchal locum tenens about the role and place of the community in the public sphere. Sergius's acquiescent or even servile attitude was still one of components of the internal organization of the community and its external relations with the authorities. The spiritual basis expressed in the document and accepted by party dissidents became an element of the internal organization of the community and its external contacts with state authorities. The Russian Church led by Metropolitan Sergius never rejected the Church party line which was already chosen in the 1920's. This text discusses the sources of Sergius's convictions and actions undertaken until the moment of the publication of The Declaration.
\end{abstract}

\begin{abstract}
Streszczenie: Relacje zachodzące między wspólnotą a władzą komunistyczną stanowiły fundamentalną sferę zainteresowania Rosyjskiego Kościoła Prawosławnego w pierwszej ćwierci XX wieku. Jeden z projektów legalizacji, podstawowego warunku utrzymania Cerkwi patriarszej w charakterze instytucji legalnej i tolerowanej przez aparat państwa, należał do metropolity niżnienowogrodzkiego Siergieja (Stragorodzkiego) - zastępcy strażnika tronu patriarszego (1925-1937), następnie strażnika tronu patriarszego (1937-1943) i patriarchy moskiewskiego i całej Rusi (1943-1944). Siergiejowy program pokojowego, ugodowego i ustępliwego wręcz współżycia Kościoła prawosławnego z przedstawicielami partii komunistycznej, wyrażony ostatecznie w jego słynnej Deklaracji z 29 lipca 1927 roku, wyrósł na gruncie wewnętrznych przekonań duchownego, ujawniających się jeszcze w okresie przedrewolucyjnym oraz poglądów patriarszego locum tenens na rolę i miejsce wspólnoty w przestrzeni publicznej, kształtowanej przez standardy komunistyczne. Postawa duchownego, wyrażona w dokumencie i przyjęta przez partyjnych decydentów, stała się elementem wewnętrznej organizacji wspólnoty oraz jej zewnętrznych kontaktów z władzą państwową. Cerkiew rosyjska kierowana przez metropolitę Siergieja nigdy nie wyrzekła się bowiem obranej przez niego już w latach dwudziestych cerkiewnej linii politycznej. O źródłach przekonań Siergieja i podejmowanych działaniach do momentu publikacji Deklaracji traktuje właśnie niniejszy tekst.
\end{abstract}

Keywords: Sergius Stragorodsky (Patriarch of Moscow, patriarchal locum tenens), The Declaration of Loyalty, Russian Orthodox Church - Soviet state relations

Słowa kluczowe: Siergiej (Stragorodzki), deklaracja lojalności, Rosyjska Cerkiew prawosławna i państwo sowieckie - relacje wzajemne

Przyszły patriarcha Siergiej przyszedł na świat 11 stycznia 1867 roku w Arzamasie jako Iwan, syn duchownego Nikołaja Stragorodzkiego ${ }^{1}$. Chłopiec, pielęgnując tradycje rodzinne, otrzymał pierwszorzędne wykształcenie cerkiewne. Edukację religijną na poziomie podstawowym uzyskał w szkole parafialnej, kontynuował zaś w arzamaskiej niższej szkole duchownej ${ }^{2}$. W wieku dziewiętnastu lat ukończył seminarium duchowne w Niżnym Nowogrodzie, po czym rozpoczął studia teologiczne w Petersburskiej Akademii Duchownej, uczelni słynącej z wysokiego poziomu nauczania i bogatej historii ${ }^{3}$.

W czasie studiów, 30 stycznia 1890 roku, młody Stragorodzki złożył śluby zakonne przyjmując, na cześć świę-

С. В. Фомин, Страж Дома Господня. Патриарх Московский и всея Руси Сергий (Страгородский): жертвенный подвиг стояния в истине православия, Москва 2003, с. 7-8.

2 Патриарх Сергий и его духовное наследство, Москва 1947, с. 14-15.

С. С. Бычков, Большевики против Русской Церкви. Очерки по истории Русской Церкви (1917-1941 г2.), Москва 2006, т. 2, с. 241. tego mnicha $\mathrm{z}$ Wałaamu, imię Siergiej4. W ciągu kolejnych trzech miesięcy został wyświęcony na hierodiakona, a następnie na hieromnicha. W maju tegoż roku uzyskał pierwszy tytuł naukowy za studium teologiczne Prawosławie o wierze i dobrych uczynkach ${ }^{5}$. Studium dyplomowe stanowiło próbę zakreślenia rozwoju doktryny soteriologicznej rosyjskiego prawosławia, opartej na tradycji patrystycznej. Nauce o zbawieniu teolog poświęcił także swoją pracę magisterską, obronioną w 1895 roku$^{6}$. Rozprawa ta, ujawniająca głęboką religijność Siergieja i jego nieprzeciętne zdolności, wyniosła młodego magistra w szereg wybitnych prawosławnych teologów końca XIX wieku?

\footnotetext{
4 Иоанн (Снычёв), Стояние в вере. Очерки иерковной смуты, СанктПетербург 1995, с. 18.

5 М. Б. Данилушкин, Т. К. Никольская, М. В. Шкаровский, В. П. Дмитриев, Б. П. Кутузов, История Русской Православной Церкви. От восстановления патриаршества до наших дней 1917-1970 г2., СанктПетербург 1997, т. 1, с. 271.

6 Патриарх Сергий и его духовное наследство..., с. 195, 197-198.

А. Г. Кравецкий, А. А. Плетнева, Патриарх Сергий как литургист,
} 
Wyrwę w życiorysie naukowym duchownego stanowił epizod japoński. Po ukończeniu Akademii hieromnich Stragorodzki zgłosił się do udziału w rosyjskiej misji w Tokio. Misjonarz w niedługim czasie opanował język japoński, dzięki czemu otrzymał posadę wykładowcy teologii dogmatycznej w seminariach duchownych w Kioto i Tokio. Z polecenia arcybiskupa Nikołaja (Kasatkina) przełom lat 18911892 spędził ponadto na okręcie „Pamięć Azowa”" Decyzja o powrocie do kraju nadeszła już w roku następnym ${ }^{9}$. Synod wyznaczył Siergieja na stanowisko docenta w katedrze Pisma Świętego Starego Testamentu w macierzystej uczelni, następnie zaś przeniósł go do Moskiewskiej Akademii Duchownej w charakterze inspektora ${ }^{10}$. Jeszcze w czasie pracy w Siergijewym Posadzie duchowny wyjechał do Aten, by objąć zarząd cerkwi przy ambasadzie rosyjskiej. Tam też został wyniesiony do godności archimandryty ${ }^{11}$. Z Grecji nowo mianowanego wysłano znów do Japonii ${ }^{12}$. Na wyspie przebywał do 1899 roku, po czym wrócił do Petersburga, by objąć stanowisko rektora seminarium duchownego, a następnie inspektora Akademii Duchownej. 21 stycznia 1901 roku Siergieja wybrano rektorem tejże uczelni ${ }^{13}$.

Dnia 25 lutego w Ławrze Aleksandra Newskiego wyświęcono Siergieja na biskupa jamburskiego, trzeciego wikariusza diecezji petersburskiej. Konsekratorami byli metropolita petersburski Antonij (Wadkowski), metropolita kijowski i halicki Fieognost (Lebiediew), metropolita moskiewski Władimir (Bogojawlenski), arcybiskup chełmski i warszawski Jeronim (Egziemplarski), biskup kiszyniowski Jakow (Piatnicki), biskup gdowski Weniamin (Muratowski), biskup narewski Nikon (Sofijski) oraz biskup sarapulski Władimir (Błagorazumow) ${ }^{14}$. W słowie podziękowania młody biskup wyłożył, w ogólnym zarysie, swoją wizję posługi pasterskiej:

„Być pasterzem to znaczy odsunąć od siebie swoje życie i żyć życiem swojej pastwy, odczuwać jej cierpienia, nieść jej smutki, a wszystko to w jednym celu: doprowadzić ją do zbawienia; umrzeć, aby ona mogła żyć. Prawdziwy pasterz nieustępliwie, w każdym swoim działaniu «oddaje duszę za owce swoje», rezygnuje z siebie, z nawyków i udogodnień, ze swoich ambicji; jest gotowy poświęcić życie, a nawet duszę w imię dobra Cerkwi Chrystusowej, w imię duchowego dobra swojego stada"15.

Dnia 6 października 1905 roku Siergieja, po wyniesieniu do godności arcybiskupiej, przeniesiono na katedrę

\footnotetext{
„Журнал Московской Патриархии”,1994, № 5, s. 37-49.

8 О. Ю. Васильева, Митрополит Сергий (Страгородский). Штрихи к nортрету, „Альфа и Омега”, 2002, № 1, с. 136-137. Zob. też: Сергий (Страгородский), По Японии. Записки миссионера, Москва 1998.

Путь моей жизни. Воспоминания митрополита Евлогия (Георгиевского), изложенные по его рассказам Т. Манохиной, Москва 1994, c. 109.

10 Патриарх Сергий и его духовное наследство..., с. 23.

1 С. В. Фомин, op. cit., с. 12.

12 С. С. Бычков, op. cit., с. 242.

М. А. Бабкин, Духовенство Русской православной церкви и свержение монархии, начало ХХ в.-конеи, 1917 г., Москва 2007, с. 131.

14 Наречение во епископь, „Церковные ведомости”, 1901, № 5, с. 30.

15 Сергий (Страгородский), Слова и речи, Санкт-Петербург 1905, c. 3-4.
}

fińską i wyborską ${ }^{16}$. W nowym środowisku wykorzystał w pełni swoje doświadczenia misjonarskie. Krzewienie prawosławia wśród mieszkańców północy, stanowiące priorytet $\mathrm{w}$ działalności arcybiskupa, realizowano poprzez organizację ośrodków misjonarskich, mianowanie nowych duszpasterzy, powoływanie zjazdów diecezjalnych. W czasie posługi arcypasterskiej Siergiej został włączony, początkowo w charakterze uczestnika czasowego, a od 1911 roku jako członek stały, do grona hierarchów Synodu ${ }^{17}$. W ramach prac zgromadzenia zajmował się korektą ksiąg liturgicznych oraz porównaniem treści poszczególnych modlitw z zapisem rękopisów ruskich i oryginałów greckich, przewodniczył sekcji misji wewnętrznej i zewnętrznej, kierował komitetem do spraw edukacji religijnej. Za pracę na rzecz wspólnoty został nagrodzony prawem noszenia brylantowego krzyża na kłobuku ${ }^{18}$.

Poglądy Siergieja, prezentowane na forum synodalnym, charakteryzowała lojalność wobec świeckiej władzy zwierzchniej. Duchowny był zwolennikiem oberprokuratora Władimira Sablera ${ }^{19}$. Efektem ich współpracy w dziedzinie edukacji religijnej była nowelizacja w ustawie szkolnej, zakładająca powołanie w akademiach duchownych samodzielnych katedr liturgiki, historii Rosji i powszechnej oraz historii schizm i sektanctwa. Wprowadzała ona także specjalne zniżki dla studentów-mnichów aspirujących do pracy naukowej ${ }^{20}$. Obiektem zabiegów Siergieja była ponadto regulacja stosunków między państwem a Kościołem. W jego projekcie zauważalna jest pewna dychotomia dążeń. Z jednej strony, krytykując model synodalny, stał na pozycji częściowej niezależności i autonomii Cerkwi, z drugiej zaś sugerował udział biskupów w organach władzy państwowej, a więc w Radzie Państwa i Dumie i postulował uznanie norm i ustaw cerkiewnych za obowiązujące prawo państwowe ${ }^{21}$.

Program cerkiewnego reformatorstwa przewartościował upadek systemu monarchicznego w Rosji. Dnia 15 marca Mikołaj II podpisał akt abdykacji, w którym oddawał władzę w ręce wielkiego księcia Michaiła Aleksandrowicza. Odrzucenie korony przez tegoż ostatniego przypieczętowało upadek państwa Romanowów. Fala rewolucyjna zniosła z powierzchni życia publicznego monarchię i doprowadziła do utworzenia w miejsce jedynowładzy carskiej Rządu Tymczasowego ${ }^{22}$.

16 М. И. Одинцов, Русские патриархи ХХ века. Судьбы Отечества и Церкви на странииах архивных документов, Москва 1999, с. 150 $-153,201,204-205$.

Состав Святейшего Правительствующего Всероссийского Синода и российской иерковной иерархии на 1917 год, Петроград 1917, c. 36-37.

18 М. Б. Данилушкин, Т. К.Никольская, М. В. Шкаровский, В. П. Дмитриев, Б. П. Кутузов, ор. cit., с. 742.

Николай (Любимов), Дневник о заседаниях вновь сбормированного Синода, [в:] Российская Церковь в годы революиии, ред. М. И. Одинцов, Москва 1995, с. 92.

20 Петр (Еремеев), Проблемы ребормирования высшей духовной школь в России в начале ХХ века, Сергиев Посад 1999 [машинопись: Московская Духовная Академия], с. 79.

${ }^{21}$ Илия (Соловьёв), Собор и патриарх. Дискуссия о высшем иерковном управлении, „Церков и время”, 2004, № 1, с. 168.

22 Rząd Tymczasowy został utworzony w Rosji 15 marca 1917 roku w wyniku porozumienia Komitetu Tymczasowego Dumy i Piotrogrodzkiej Rady Delegatów Robotniczych i Żołnierskich. Pierwszym premierem 
Przedstawicielem strony rządzącej, pełniącym jednocześnie funkcje ministra i oberprokuratora, został mianowany Władimir Lwow. Desygnacja na to stanowisko była wynikiem jego wieloletniej działalności politycznej. Po zakończeniu studiów na wydziale filologiczno-historycznym i prawnym Uniwersytetu Moskiewskiego, zapisał się jako wolny słuchacz na wykłady prowadzone w Moskiewskiej Akademii Duchownej. Wtedy też podjął decyzję o przyjęciu ślubów zakonnych. Zamiast kapłaństwa wybrał ostatecznie politykę. Był deputatem Dumy trzeciej i czwartej kadencji oraz przewodniczącym Komisji do spraw Cerkwi ${ }^{23}$.

Polityka cerkiewna rewolucyjnego oberprokuratora była realizowana $\mathrm{w}$ sposób sprzeczny $\mathrm{z}$ wolą hierarchów. Różnice między jedną a drugą stroną dotyczyły sposobu rozumienia pojęcia wolność. Dla wyższego duchowieństwa oznaczało ono zrzucenie blisko dwustuletniej opieki władzy państwowej, dla Lwowa natomiast stało się synonimem wyzwolenia Cerkwi rosyjskiej spod dyktatu biskupów ${ }^{24}$. Rewolucja społeczna i polityczna, która wyniosła na powierzchnię życia publicznego Rząd Tymczasowy, miała stać się zarzewiem rewolty wewnątrzcerkiewnej ${ }^{25}$.

Taktyka, jaką obrał Lwow, nie odróżniała się niczym od metod postępowania jego poprzedników - nominatów carskich $^{26}$. Dnia 27 kwietnia 1917 roku rozwiązał sesję zimową Synodu, pozostającego w opozycji wobec jego działań. Do nowo powołanego zgromadzenia w kadencji letniej nie zaproszono żadnego z członków rozwiązanego ciała, za wyjątkiem arcybiskupa finlandzkiego Siergieja. Pozostawienie tego hierarchy na stanowisku należy tłumaczyć lojalną postawą hierarchy wobec nowej władzy świeckiej. Nikołaj Lubimow charakteryzował Siergieja jako człowieka chcącego ze wszystkich miar przypodobać się Lwowowi i umiejącego przystosować się do każdych warunków. Oberprokurator dostrzegał w nim swojego sprzymierzeńca i osobę godną zaufania ${ }^{27}$.

Strategia oberprokuratora sprzęgła się z oczekiwaniami prawosławnej części społeczeństwa. Ich żądania, obok osobistych ambicji polityka, legły u podstaw tak zwanej „rewolucji cerkiewnej”. Wiosną i latem 1917 na terytorium całej Rosji organizowano zjazdy niższego duchowieństwa i osób świeckich. Idea tych zgromadzeń, stawiająca na udział czynnika społecznego w zarządzie, miała wprowadzić zasadę demokratycznej wybieralności władz zwierzch-

Rządu był książę Gieorgij Lwow, którego (od 21 lipca) na stanowisku premiera zastąpił Aleksander Kiereński. Zob.: P. Kenez, Odkłamana historia Związku Radzieckiego, przeł. A. Górska, Warszawa 2008, s. 30-38.

23 ГАРФ, Чрезвычайная следственная комиссия для расстедования противозаконных по должности действий бывших министров и прочих выстих должностных лии, ф. 1467, оп. 1, д. 572, л. 7 об.

${ }_{24}$ Иакинф Дестивель, Поместный Собор Российской Православной Церкви 1917-1918 г2. и принии соборности, Москва 2008, с. 83-84.

25 И. Смолич, История Русской Церкви 1700 - 1917, Москва 1997, c. 723 .

26 А. В. Карташёв, Революция и Собор 1917-1918 гг. (наброски для истории Русской Церкви наших дней), [в:] Дело великого строительства иерковного. Воспоминания иленов Священного Собора Православной Российской Церкви 1917-1918 годов, ред. В. Н. Воробьёв, Москва 2009, с. 490.

27 Николай (Любимов), Дневник о заседаниях вновь сформированного Синода, [в:] Российская Церковь в годы революиии, ред. М. И. Одинцов, Москва 1995, с. 92. nich w Kościele prawosławnym. Nastroje panujące wśród zebranych na zjazdach elektorów nosiły znamiona rewolucji. Radykalizm ich poglądów, wyrażający się w niezadowoleniu z dotychczasowej administracji biskupów w terenie, doprowadził do oddolnego usuwania hierarchów z zajmowanych stanowisk. Na ich miejsce powoływano, zgodnie $\mathrm{z}$ duchem demokracji, nowych zarządców. W ten sposób $\mathrm{w}$ katedrze włodzimierskiej zasiadł arcybiskup finlandzki Siergiej ${ }^{28}$.

Postanowienie Synodu, potwierdzające wyniki wyborów w terenie, zostało wydane 10 sierpnia. Na tym stanowisku zastąpił arcybiskupa Aleksieja (Dorodnicyna) ${ }^{29}$. Diecezja włodzimierska była jedną z najstarszych jednostek administracyjnych Cerkwi rosyjskiej. W początkach XX wieku przodowała wśród pozostałych pod względem rozległości obszaru. Wiekowe zaległości w sferze zarządu, powstałe w wyniku braku jednego ośrodka koordynacyjnego i podległych mu komórek, zniwelowano dopiero w czasach posługi arcybiskupiej Siergieja. Sukcesem jego pięcioletnich rządów był podział diecezji na pięć okręgów metropolitalnych i pięć wikariatów, co usprawniło proces współpracy między jednostkami terenowymi i centrum ${ }^{30}$.

28 listopada 1917 roku, decyzją Soboru Lokalnego, Siergiej został wyniesiony do godności metropolity ${ }^{31}$. Zbiegający się z otwarciem zgromadzenia soborowego przewrót bolszewicki diametralnie zmienił warunki posługi kapłańskiej i charakter jego działalności duszpasterskiej oraz życie religijne całej wspólnoty. Droga, która poprowadziła duchownego na tron patriarszy wiodła przez komunistyczne więzienia i współpracę z „odnowicielskim” Najwyższym Zarządem Cerkwi.

Siergiej wraz z pozostałymi sygnatariuszami Memorandum trzech - arcybiskupami Jewdokimem (Mieszczerskim) i Serafinem (Mieszczeriakowem) uznali Zarząd za przedstawicielstwo ,jedynej władzy cerkiewnej" ${ }^{32}$. Niecały rok później, 28 czerwca 1923 roku, metropolita, podczas uroczystej liturgii sprawowanej przez patriarchę Tichona w Monasterze Dońskim, dokonał publicznego aktu skruchy. W czasie nabożeństwa zwierzchnik Kościoła prawosławnego włożył na niego krzyż i panagię, zaś arcybiskup wierejski Iłarion (Troicki) wręczył mu biały kłobuk. Siergiej został przyjęty do wspólnoty jako jej pełnoprawny członek $^{33}$.

\footnotetext{
28 П. Г. Рогозный, „Церковная революиия”: март-август 1917 года, [в:] 1917-й: Церковь и судьбы России. Материаль международной научной конференции. К 90-летию Поместного Собора и избрания Патриарха Тихона, ред. В. Н. Воробьёв, Москва 2008, с. 56-63.

29 Сергий (Минин), Очерки по истории владимирской епрахии X-XX вв., Владимир 2004, с. 51.

30 O działalności Siergieja zob.: ibidem, c. 51-54.

31 М. А. Бабкин, op. cit., с. 329;

32 Д. В. Сафонов, Митрополит Сергий (Страгородский) и советская власть в 1921-1926 г2., [в:] ХІХ Ежегодная Богословская конферениия Православного Свято-Тихоновского Богословского Института. Материаль, ред. В. Н. Воробьёв, Москва 2009, т. 1, с. 273-281; idem, Деятельность митрополита Сергия (Страгородского) в контексте советской вероисповедной политики в 1921-1926 г2., „Вестник Челябинского государственного университета. История”, 2009, № 23, вып. 33, с. 58-66.

33 А. Левитин, В. Шавров, Очерки по истории русской иерковной смуты в 3 томах, Кюснахт 1977-1978, т. 2, с. 170.
} 
Epizod „odnowicielski” osłabił pozycję metropolity niżnienowogrodzkiego (od 1925 roku) wśród współbraci i zwrócił uwagę sowieckich organów bezpieczeństwa, poszukujących możliwości rozbicia jedności Kościoła rosyjskiego. Pomysł budowy platformy porozumienia i oficjalnego współdziałania między Cerkwią patriarszą a różnymi denominacjami „Żywej Cerkwi” zyskał aprobatę sowieckiego „oberprokuratora” - Jewgienija Tuczkowa. Przewodniczący Komisji Antyreligijnej widział w ruchu „odnowienia” przeciwwagę tendencjom propatriarszym w Cerkwi rosyjskiej ${ }^{34}$. Metropolitę Siergieja wyznaczono na autora wykładu, zarysowującego teologiczny fundament pod budowę stosunków między państwem a Kościołem prawosławnym ${ }^{35}$.

$\mathrm{W}$ dokumencie, przedstawionym pod rozpatrzenie Tuczkowa, można wydzielić trzy części. Pierwsza, stanowiąca rys historyczny, analizowała funkcjonowanie wspólnoty $\mathrm{w}$ przestrzeni politycznej państwa sowieckiego ${ }^{36}$. Hierarcha podkreślał znaczenie antyreligijnych wartości komunistycznych w tworzeniu podstaw życia publicznego. Rosja bezbożna, ateistyczna traktowała jakiekolwiek zaangażowanie religijne swoich obywateli jako działanie skierowane przeciwko władzy. Każdy związek wyznaniowy był politycznym konkurentem partii rządzącej. Wrogość bolszewików wobec wiernych i duchownych prawosławnych wynikała zatem, jak twierdził Siergiej, z pobudek ideologicznych, z przyjętej linii politycznej. Władza sowiecka nie wychodziła przy tym, kontynuował hierarcha, poza ramy praworządnego państwa. Realizacja dekretu O oddzieleniu Cerkwi od państwa wyznaczyła wspólnocie obszar swobodnego funkcjonowania. „Nasze świątynie są otwarte, kazania są głoszone, każdy może z nich korzystać" - egzemplifikowa ${ }^{37}$. Odrzucając wizję Cerkwi prześladowanej, poddawanej fizycznej eksterminacji i pozbawianej majątku nieruchomego, Siergiej dostrzegał jedynie pewne ograniczenia nałożone na wspólnotę. Miały one wymiar transcendentny, mesjanistyczny. Przybliżały do osiągnięcia ideału chrześcijańskiej pokory i oddania woli Bożej. Umożliwiały także pielęgnację wartości najwyższych, w których obronie należało oddać życie ${ }^{38}$.

Druga część wykładu zawierała projekt regulacji stosunków między Cerkwią i państwem sowieckim ${ }^{39}$. Koncentrował się on wokół pojęcia lojalności, które rozumiał $\mathrm{w}$ kategorii praworządności, działania $\mathrm{w}$ ramach obowiązującego prawa państwowego, współpracy z partią rządzącą, odżegnania się od wrogów ojczyzny sowieckiej i agitacji

\footnotetext{
34 С. С. Бычков, op. cit., с. 253.

35 С. Л. Фирсов, Время в судьбе. Святейший Сергий Патриарх Московский и Всея Руси. К вопросу о генезисе „сергианства” в русской иерковной традиции ХХ века, Санкт-Петербург 1999, с. 103; Д. В. Сафонов, Высшее Управление Русской православной церкви в 1921-1925 г2. в контексте государственно-иерковных отношений, автореферат диссертации, Сергиев Посад 2010 [машинопись: Московская Духовная Академия], с. 25.

36 Следственное дело патриарха Тихона. Сборник документов по материалам Центрального архива ФСБ Российской Федераиии, сост. Н. А. Кривова, Москва 2000, с. 784-786.

37 Ibidem, c. 787

38 Ibidem, c. 786.

Ibidem, c. 786-794
}

przeciwko niej ${ }^{40}$. Siergiejowy konspekt nie zakładał jednak politycznego zaangażowania duchowieństwa. Wspólnota kierować się miała zasadami chrześcijańskimi oraz dobrem całego kraju i wszystkich jego obywateli. Przewrót bolszewicki, twierdził hierarcha, zerwał wielowiekową zależność Kościoła prawosławnego od ustroju samodzierżawnego i jego przedstawicieli, zarówno świeckich, jak i duchownych $^{41}$. Wolność, przyniesioną na fali rewolucji, powinni wykorzystać wszyscy wierzący, odgradzający się od swoich zapatrywań politycznych. Od przyszłego zgromadzenia soborowego Siergiej oczekiwał odwołania tradycyjnej przysięgi wierności imperatorowi oraz ogłoszenia lojalności wobec nowej władzy i jej liderów ${ }^{42}$.

Trzecia, najbardziej interesująca część dokumentu analizowała rosyjski wariant „komunizmu chrześcijańskiego”. Siergiej pisał:

„ustrój ten nie jest przeciwny chrześcijaństwu, sprzyja on chrześcijaństwu bardziej niż jakikolwiek inny system polityczny. Potwierdza to historia chrześcijaństwa na świecie, kiedy to wspólnota nie miała jasnego wyobrażenia o ramach swojego funkcjonowania, przykładała swoje zasady do budowy życia wewnętrznego pierwszej wspólnoty chrześcijańskiej w Jerozolimie" ${ }^{\text {43. }}$.

Pierwsze gminy kultywowały ideał wspólnotowości, oparty na silnych związkach międzyludzkich, na pracy na rzecz wspólnego dobra. Teolog, niejako wbrew swojej intuicji religijnej, wzorzec ów podparł wyselekcjonowanymi wywodami historycznymi. Wybór dokonany przez Siergieja był zorientowany na czynnik ekonomiczny ${ }^{44}$. Odwołując się do czasów Katarzyny II, Piotra I i współczesności dostojnik wskazywał, iż realizowana przez władców rosyjskich polityka fiskalna miała głęboki sens religijny. Uszczuplanie majątku Cerkwi rosyjskiej pozwoliło bowiem, jak twierdził metropolita, oczyścić wiarę z ludzkich słabości, skłonności od gromadzenia bogactwa, życia w blichtrze i luksusie. Kościołowi prawosławnemu potrzeba było odrzucić ów balast, aby w pełni nieść swoje prawdziwe posłannictwo. Wolność, o której pisał duchowny, oznaczała dotarcie do korzeni chrześcijaństwa, umożliwiała odbudowę dawnych ideałów równości, sprawiedliwości społecznej i braterstwa ${ }^{45}$.

„Oto dlaczego jestem przekonany - reasumował - że przyjęcie komunizmu jako manifestu ekonomicznego (zupełnie odrzucając kwestie religijne) oznacza dla naszej Cerkwi powrót do zapomnianych oficjalnie, ale żyjących nadal w duszach wierzącego narodu, wartości”46.

\footnotetext{
40 Por.: С. Л. Фирсов, Время в судьбе. Святейший Сергий Патриарх Московский и Всея Руси. К вопросу о генезисе „сергианства” в русской иерковной традиции ХХ века, Санкт-Петербург 1999, с. 97-108.

${ }_{41}$ Следственное дело патриарха Тихона. Сборник документов по материалам Центрального архива ФСБ Российской Федерации..., c. 790 .

42 Ibidem, c. 793-798

43 Ibidem, c. 794.

44 Ibidem, c. 796-797.

45 Ibidem, c. 795.

46 Ibidem, c. 797
} 
Projekt metropolity Siergieja nie został zaakceptowany przez naczelne organy cerkiewne. Idea dialogu między przedstawicielami Cerkwi patriarszej i członkami ruchu „odnowienia”, opartego na zasadach częściowego ustępstwa, została odrzucona przez strażnika tronu patriarszego - metropolitę krutickiego Piotra (Polanskiego).

Locum tenens, świadom rzeczywistego źródła siły ruchu „odnowienia”, nie przyjął zarazem oferty porozumienia $\mathrm{z}$ ich komunistycznymi protektorami ${ }^{47}$. Forsowany przez Komisję Antyreligijną projekt legalizacji - jedynego warunku utrzymania Cerkwi patriarszej w charakterze instytucji legalnej i tolerowanej przez aparat państwa - upadł. Legalizacja, $\mathrm{w}$ rozumieniu partyjnych decydentów, była równoznaczna $\mathrm{z}$ podpisaniem przez Piotra deklaracji lojalności wobec władzy sowieckiej. Zawierać ona miała, zgodnie z odgórnymi dyrektywami, obietnicę usunięcia niewygodnych kapłanów z szeregu wyższego duchowieństwa cerkiewnego oraz oświadczenie o współpracy $\mathrm{z}$ instytucjami rządowymi ${ }^{48}$.

W nocy z 9 na 10 grudnia metropolita Piotr został, na mocy decyzji naczelnych władz partyjnych, zatrzymany ${ }^{49}$. Świadomość paraliżu ciągłości funkcjonowania instytucji kościelnych wpłynęła najprawdopodobniej na postępowanie strażnika tronu patriarszego, który na kilka dni przed zatrzymaniem podpisał akty dotyczące porządku dziedziczenia najwyższej władzy cerkiewnej. Metropolita Piotr, obdarzony władzą zwierzchnią w wyniku realizacji przez Tichona postanowienia soborowego z 1918 roku, zabezpieczył dziedziczność tytułu patriarszego na wypadek niemożności kontynuowania normalnej posługi. Powtórzył tym samym precedens $\mathrm{w}$ kanonicznym porządku przewodnictwa rosyjskiemu prawosławiu, wymuszony politycznymi warunkami funkcjonowania wspólnoty. Pierwszy z tych dokumentów, datowany na 5 grudnia, otrzymał następujące brzmienie:

„W wypadku naszej śmierci prawa i obowiązki strażnika tronu patriarszego wygasające $\mathrm{w}$ chwili kanonicznego wyboru nowego patriarchy, przekazujemy - zgodnie z wolą świętej pamięci patriarchy Tichona - metropolitom kazańskiemu Kiryłowi [Smirnowowi] i jarosławskiemu Agatangelowi [Prieobrażenskiemu]. Niemożność objęcia przez któregokolwiek z nich funkcji spowoduje przekazanie władzy w ręce metropolity Arsenija [Stadnickiego]. Jeśli także on nie będzie mógł zrealizować tegoż postanowienia, to prawa i obowiązki strażnika tronu patriarszego przekazujemy metropolicie niżnienowogrodzkiemu Siergiejowi Stragorodzkie$\mathrm{mu}{ }^{350}$.

\footnotetext{
47 Д. В. Сафонов, Высшее Управление Русской православной иеркви в 1921-1925 г2. в контексте государственно-иерковных отночений..., с. 30. Por.: Архивы Кремля. Политбюро и иерковь 1922-1925 г2., сост. Н. Н. Покровский, С. Г. Петров, Москва, Новосибирск 1998, кн. 2, c. 517.

48 Л. Регельсон, Трагедия Русской Церкви 1917-1945, Москва 2007, c. 389 .

49 М. Б. Данилушкин, Т. К. Никольская, М. В. Шкаровский, В. П. Дмитриев, Б. П. Кутузов, оp. cit., с. 208; Т. Н. Коголь, op. cit., с. 120.

50 Суt. za: Владислав (Цыпин), История Русской Православной Церкви. Синодальный и новейший периоды (1700-2005), Москва 2007,
}

Dnia 6 grudnia metropolita Piotr zmienił zapis powyższego postanowienia, ponownie typując swoich następców $\mathrm{w}$ godności locum tenens. Odchodząc od rozporządzenia Tichona, duchowny wyznaczył kolejno metropolitę Siergieja, egzarchę Ukrainy Michaiła (Jermakowa) i arcybiskupa rostowskiego Josifa (Pietrowych) ${ }^{51}$. W chwili aresztu postanowienie metropolity krutickiego weszło w życie, komplikując położenie jego następcy. Siergiej, informując 14 grudnia o przejęciu obowiązków, stanął w praktyce na czele Kościoła prawosławnego ${ }^{52}$. Nie był jednak ani patriarchą, ani nawet jego następcą. Piotr bowiem nie wyrzekł się swojej władzy, nie został jej pozbawiony przez sąd cerkiewny. Pozostawał w teorii kanoniczną głową Cerkwi rosyjskiej. Metropolita Siergiej pozostawał zastępca strażnika tronu patriarszego - zastępcą zastępcy patriarchy ${ }^{53}$.

Ustanowienie jedynowładztwa w strukturach Cerkwi patriarszej nie rozwiązało większości problemów wspólnoty. Siergiej, świadom niestabilności kościelnych struktur administracyjnych, podjął się pertraktacji z przedstawicielami władzy ${ }^{54}$. Ich celem była państwowa rejestracja (legalizacja) najwyższych organów zarządu Kościołem prawosławnym. Pojęcie legalizacji w świetle prawa sowieckiego oznaczało nadanie ubiegającej się o rejestrację instytucji charakteru osoby prawnej ${ }^{55}$. Nie stanowiąc podmiotu prawa cywilnego Cerkiew, jak podkreślał metropolita niżnienowogrodzki w swoim liście do władz z 10 czerwca, była obiektem prześladowania ze strony aparatu państwa. Niezarejestrowany oznaczało bowiem tyle co nielegalny, reakcyjny, kontrrewolucyjny. Hierarcha prosił o zalegalizowanie działalności naczelnych instytucji ustawodawczych i prawodawczych (nie konkretyzując o jakie organy chodzi), patriarszej kancelarii, zajazdów diecezjalnych, synodu arcybiskupiego oraz centralnego wydawnictwa cerkiewnego ${ }^{56}$. Ceną, jaką gotowy był zapłacić zastępca strażnika tronu patriarszego, była oczywiście lojalność wspólnoty wobec władzy sowieckiej i jej przedstawicieli. „Otrzymując prawa legalnego funkcjonowania - podkreślał - zdajemy sobie sprawę z tego, że wraz z nimi przyjmujemy na siebie obowiązki w stosunku do tej władzy, która nam je nadała"s7.

Oferta duchownego latem 1926 roku nie zainteresowała członków Komisji Antyreligijnej. Odezwa do władzy sowieckiej została oficjalnie zignorowana. Nieoficjalnie zaś metropolita został poddany ścisłej inwigilacji przez aparat

c. 411. Zob. też: A. Мазырин, Высшие иерархи о преемстве власти в Русской Православной Церкви в 1920-х - 1930-х годах, Москва 2006, c. 67.

51 Владислав (Цыпин), op. cit.., с. 411-412.

52 М. Б. Данилушкин, Т. К.Никольская, М. В. Шкаровский, В. П. Дмитриев, Б. П. Кутузов, ор. cit., с. 281-28.

А. Мазырин, ор. cit., с. 387. Por.: idem, Om Святейшего Тихона к Святейшему Сергию: вопрос о патриапшем строе в 1920-1930-е годь, [в:] 1917-й: Церковь и судьбы России. К 90-летью Поместного Собора и избрания Патриарха Тихона, ред. В. Н. Воробьёв, Москва 2008,, с. 181-197.

54 С. В. Троицкий, Размежеание или раскол, Париж 1932, с. 33.

55 Д. В. Поспеловский, Русская Православная Церковь в ХХ в., Москва 1995, с. 114-115.

56 О. Ю. Васильева, Жребий митрополита Сергия (от „Декларации” до „Памятной записки”), [в:] Ежегодная Богословская Конферениия Православного Свято-Тихоновского Богословского Института. Материаль, ред. В. Н. Воробьёв Москва 1997, с. 180.

57 Суt. za: М. И. Одинцов, ор. cit., с. 221-222. 
bezpieczeństwa, którego pracownicy w listopadzie zatrzymali kapłana pod zarzutem współpracy z antysowieckimi środowiskami zagranicznymi ${ }^{58}$. „Obywatel Stragorodzki” opuścił mury moskiewskiego więzienia w marcu 1927 roku, a więc po okresie trzyipółmiesięcznego odosobnienia. Ten nieoczekiwany powrót, mający miejsce w czasie apogeum wysyłek duchowieństwa do obozów pracy przymusowej, zasadniczo przyspieszył rozwój wydarzeń. Dnia 7 kwietnia duchowny został oficjalnie wyniesiony do godności zastępcy strażnika tronu patriarszego. Jako głowa Cerkwi rosyjskiej w miesiąc później zwrócił się ponownie do władz z prośbą o legalizację wyższej administracji cerkiewnej. 18 maja utworzono Tymczasowy Synod, składający się ostatecznie $\mathrm{z}$ dwunastu mianowanych hierarchów ${ }^{59}$.

Siergiej, pełniący funkcję przewodniczącego Synodu wraz z dziesięcioma członkami zgromadzenia 29 lipca wystosował Posłanie do pasterzy $i$ wiernych, znane jako Posłanie (deklaracja) zastępcy strażnika tronu patriarszego metropolity niznienowogrodzkiego Siergieja (Stragorodzkiego) i utworzonego przy nim Tymczasowego Świętego Synodu o stosunku Rosyjskiej Cerkwi Prawosławnej do władzy państwowej lub po prostu Deklaracja.

Patriarszy locum tenens, w pełni identyfikując się z prawosławną częścią społeczeństwa rosyjskiego, w skład którego wchodzili oczywiście prawosławni, sygnował posłanie jako obywatel Związku Sowieckiego. Partię rządzącą, w ujęciu tekstu, uznano oficjalnie za trwałą podporę funkcjonującego w kraju ustroju społeczno-politycznego oraz wyznacznik optymalnych standardów życia publicznego. Uznanie aparatu ustawodawczo-prawodawczego zostało wyrażone przez zastępcę strażnika tronu patriarszego następującymi słowami: „Ludzie zapomnieli, że dla chrze-

\footnotetext{
5812 września 1926 roku Siergiej dokonuje jeszcze jednego sprzecznego $\mathrm{z}$ prawem kroku - bez zgodny władz skierował on bowiem list do przebywających za granicą rosyjskich biskupów, w którym odwołał się do problemu funkcjonowania dwóch nieutrzymujących ze sobą kontaktów, gałęzi rosyjskiej Cerkwi. Zdaniem hierarchy taki podział był w gruncie rzeczy zjawiskiem pozytywnym, Chronił bowiem skuteczniej przed wzajemnymi pretensjami i konfliktami, niż mogłoby to zrobić sztucznie stworzone centrum. О. Ю. Васильева, Февральская пресс-конферениия митрополита Сергия - историческое осмысление и историческое наследие, [в:] Русская Православная Церковь в ХХ веке. Материалы конферениии, Петрозаводск 2002, с. 384-405.

${ }_{59}$ W skład Synodu, obok metropolity Siergieja, weszli: metropolita nowogrodzki Arsenij(Stadnicki), metropolita twerski Serafin (Aleksandrow), arcybiskup kostromski Sewastian (Wiesti), arcybiskup hutyński Aleksiej (Simanski), arcybiskup wiatski Paweł (Borysowski), arcybiskup zwienigorodzki Filip (Gumilewski), egzarcha Ukrainy Michaił (Jermakow), metropolita taszkiencki Nikandr (Fienomienow), arcybiskup wołogodzki Silwestr (Bratanowski), arcybiskup samarski Anatolij (Hrysiuk), biskup sumski Konstantin (Diakow), biskup sierpuchowski Siergiej (Griszyn). Zob.: Владислав (Цыпин), op. cit., c. 421-422.
}

ścijanina nie ma przypadków i to, co dokonuje się u nas, jak zawsze i wszędzie, dokonuje się ręką Bożą"60. Pod tym stwierdzeniem, jak wynika z kontekstu dokumentu, metropolita niżnienowogrodzki rozumiał nieodwracalne, niepodlegające ocenie zmiany wniesione przez przewrót bolszewicki. Hierarcha nawoływał do wierności wobec ojczyzny, do obywatelskiego posłuszeństwa. Nie mogło to być podporządkowanie ślepe i niewolnicze, wypływające z bojaźni, ale wynikające z decyzji sumienia, świadomości osobistej i zrozumienia ${ }^{61}$.

Podejmowane przez patriarszego locum tenens próby zasypania przepaści między państwem ideologicznym i Kościołem prawosławnym doprowadziły, jak podkreślają jego przeciwnicy, do zniekształcenia obrazu Kościoła w świadomości prawosławnej części społeczeństwa. Zysk polityczny będący rezultatem ustępstw - ich zdaniem był niewspółmierny w stosunku do szkód, jakie poniosła wspólnota. Targana wewnętrznymi konfliktami natury personalnej i ideologicznej, uznawana przez władze sowieckie za negatywny element rozwoju społeczno-ekonomiczno-historycznego społeczeństw Cerkiew rosyjska kierowana przez metropolitę Siergieja nigdy nie wyrzekła się obranej przez niego już w latach dwudziestych cerkiewnej linii politycznej.

Siergiejowy program pokojowego współżycia Kościoła prawosławnego z przedstawicielami partii komunistycznej wyrósł na gruncie całokształtu stosunków między rosyjskim Kościołem prawosławnym a państwem sowieckim oraz nakładających się nań poglądów patriarszego locum tenens na rolę i miejsce wspólnoty w przestrzeni publicznej, kształtowanej przez standardy komunistyczne. W Siergiejowym systemie próżno doszukiwać się przypadkowości sformułowań, niekonsekwencji postępowania i poglądów. Pomimo zmienności warunków historycznych, politycznych i społecznych, mających odzwierciedlenie w funkcjonowaniu Kościoła prawosławnego w Rosji (Cesarstwie Rosyjskim i Związku Sowieckim), ugodowa, wręcz serwilistyczna postawa Siergieja była nadal jednym z ważniejszych elementów wewnętrznej organizacji wspólnoty oraz jej zewnętrznych relacji z władzą państwową.

\footnotetext{
60 Русская Православная Церковь и коммунистическое государство 1917-1941 г2. Документы и фотоматериаль, сост. О. М. Васильева, Москва 1996, с. 227.

61 Суt. zа: Д. В. Сафонов, К вопросу о подлинности „Завещзательного послания” св. патриарха Тихона, „Богословский вестник”, 2004, № 4, c. 289.
} 


\section{Bibliografia}

Архивы Кремля. Политбюро и церковь 1922-1925 г2., сост. Н. Н. Покровский, С. Г. Петров, Москва-Новосибирск 1998, кн. 2.

Бабкин М. А., Духовенство Русской православной церкви и свержение монархии, начало ХХ в.-конеи 1917 г., Москва 2007.

Бычков С. С., Большевики против Русской Церкви. Очерки по истории Русской Церкви (1917-1941 гг.), Москва 2006, т. 2.

Васильева О. Ю., Жребий митрополита Сергия (от Деклараизи до Памятной записки), [в:] Ежегодная Богословская Конференция Православного Свято-Тихоновского Богословского Института. Материалы, ред. В. Н. Воробьёв, Москва 1997, с. 174-186.

Васильева О. Ю., Митрополит Сергий (Страгородский). Штрихи к портрету, „Альфа и Омега”, 2002, № 1, с. 136-163.

Владислав (Цыпин), История Русской Православной Церкви. Синодальный и новейший периоды (1700-2005), Москва 2010.

Данилушкин М. Б., Никольская Т. К., Шкаровский М. В., Дмитриев В. П., Кутузов Б. П., История Русской Православной Церкви. От восстановления патриариества до наших дней 1917-1970 г2., Санкт-Петербург 1997, т. 1.

Иакинф (Дестивель), Поместный Собор Российской Православной Церкви 1917-1918 г2. и принцип соборности, Москва 2008.

Илия (Соловьёв), Собор и патриарх. Дискуссия о высшем церковном управлении, „Церков и время”, 2004, № 1, с. 168-180.

Иоанн (Снычёв), Стояние в вере. Очерки иерковной смуты, Санкт-Петербург 1995.

Карташёв А. В., Революиия и Собор 1917-1918 г2. (наброски для истории Русской Церкви наших дней, [в:] Дело великого строительства иерковного. Воспоминания членов Священного Собора Православной Российской Церкви 1917-1918 годов, ред. В. Н. Воробьёв, Москва 2009. 486-527.

Кравецкий А. Г., Плетнева А. А., Патриарх Сергий как литургист, „Журнал Московской Патриархии, 1994, № 5, с. 37-49.

Мазырин А., От Святейшего Тихона к Святейшему Сергию: вопрос о патриапшем строе в 1920-1930-е годы, [в:] 1917й: Церковь и судьбы России. Материалы международной научной конферениии. К 90-летию Поместного Собора и избрания Патриарха Тихона, ред. В. Н. Воробьёв, Москва 2008, с. 181-197.

Мазырин А., Высшие иерархи о преемстве власти в Русской Православной Церкви в 1920-х - 1930-х годах, Москва 2006.

Николай (Любимов), Дневник о заседаниях вновь сформированного Синода, [в:] Российская Церковь в годы революичии, ред. М. И. Одинцов, Москва 1995, с. 15-120.

Одинцов М. И., Русские патриархи ХХ века. Судьбь Отечества и Церкви на странииах архивных документов, Москва 1999.
Патриарх Сергий и его духовное наследство, Москва 1947.

Петр (Еремеев), Проблемы ребормирования высшей духовной школь в России в начале ХХ века, Сергиев Посад 1999.

Поспеловский Д. В., Русская Православная Церковь в ХХ в., Москва 1995.

Путь моей жизни. Воспоминания митрополита Евлогия (Георгиевского), изложенные по его рассказам Т. Манохиной, Москва 1994.

Регельсон Л., Трагедия Русской Церкви 1917-1945. Москва 2007.

Рогозный П. Г., Церковная революиия: март-август 1917 года, [в:] 1917-й: Церковь и судьбы России. Материаль международной научной конферениии. К 90-летию Поместного Собора и избрания Патриарха Тихона, ред. В. Н. Воробьёв, Москва 2008, с. 56-63.

Русская Православная Церковь и коммунистическое государство 1917-1941 г2. Документы и фотоматериаль, сост. Я. Н. Щапов, Москва 1996.

Сафонов Д. В., К вопросу о подлинности „Завещательного послания” св. патриарха Тихона, „Богословский вестник”, 2004, № 4, с. 265-311.

Сафонов Д. В., Митрополит Сергий (Страгородский) и советская власть в 1921-1926 гг., [в:] ХІХ Ежегодная Богословская конференция Православного Свято-Тихоновского Богословского Института. Материаль, ред. В. Н. Воробьёв, Москва 2009, т. 1, с. 273-281.

Сафонов Д. В., Высшее Управление Русской православной церкви в 1921-1925 г2. в контексте государственно-иерковных отношений, автореферат диссертации, Сергиев Посад 2010 [машинопись: Московская Духовная Академия].

Сергий (Минин), Очерки по истории владимирской епрахии $X-X X$ вв., Владимир 2004.

Сергий (Страгородский), Слова и речи, Санкт-Петербург 1905. Следственное дело патриарха Тихона. Сборник документов по материалам Центрального архива ФСБ Российской Федерации, сост. Н. А. Кривова, Москва 2000.

Смоли И. К., История Русской Церкви 1700-1917, Москва 1997.

Состав Святейшего Правительствующего Всероссийского Синода и российской церковной иерархии на 1917 год, Петроград 1917.

Троицкий С. В., Размежеание или раскол, Париж 1932.

Фирсов С. Л., Время в судьбе. Святейший Сергий Патриарх Московский и Всея Руси. К вопросу о генезисе „сергианства” в русской церковной традиции ХХ века. Санкт-Петербур 1999.

Фомин С. В., Страж Дома Господня. Патриарх Московский и всея Руси Сергий (Страгородский): жертвенньй подвиг стояния в истине православия. Москва 2003. 